\title{
Os cientistas e seus arquivos
}

\section{Scientists and their archives}

\author{
Celso Castro \\ Professor do Centro de Pesquisa e Documentação de História Contemporânea do Brasil (CPDOC) da Fundação Getulio Vargas. \\ celso.castro@fgv.br
}



SILVA, Maria Celina Soares de Mello e; SANTOS, Paulo Roberto Elian dos (Org.). Arquivos pessoais: história, preservação e memória da ciência. Rio de Janeiro: Associação dos Arquivistas Brasileiros, 2012. 192p.
$\mathrm{E}$ ste livro reúne nove capítulos que tratam de arquivos pessoais de cientistas, incluindo desde personagens muito conhecidos no campo científico brasileiro até outros quase desconhecidos. Repleto de informações sobre a vida e os documentos desses personagens, o livro abre importante espaço às descrições dos modos pelos quais seus arquivos foram organizados. Nesse sentido, além do interesse específico que cada arquivo examinado possa ter para uma determinada área do conhecimento, o livro, em seu conjunto, constitui-se também em bem-vinda contribuição à infelizmente pequena bibliografia disponível sobre arquivos pessoais. O capítulo sobre a reorganização do arquivo do astrônomo Henrique Morize, em particular, destaca-se pelo caráter exemplar, ao mesmo tempo didático e meticuloso, com que trata as complexidades das diferentes etapas do processo.

Especialmente interessantes são as tentativas, presentes em vários capítulos, de definir um método de organização mais adequado, em geral, aos arquivos pessoais de cientistas. Parte-se de uma recorrente

crítica ao 'método CPDOC' de tratamento de arquivos pessoais que, embora reconheça a originalidade e importância histórica da instituição, criada em 1973, aponta seu caráter supostamente descontextualizador e incompatível com a moderna arquivística. Imagino que isso se deva a uma leitura parcial, senão mesmo equivocada, de uma edição dos procedimentos técnicos adotados pela instituição, publicada em 1998. Nos 15 anos que se seguiram, esses procedimentos continuaram a evoluir em função do impacto decisivo da informatização dos instrumentos de busca e da adoção da digitalização e da divulgação pela internet como mecanismos preferenciais de preservação e acesso ao acervo. $\mathrm{O}$ arranjo usado no CPDOC, de qualquer modo, sempre buscou respeitar princípios fundamentais da arquivística, como os que dizem respeito à proveniência dos fundos, mantidos em sua integralidade e organicidade, e a atenção ao arranjo original, por mais que fosse necessário adaptá-lo e eventualmente modificá-lo, em função de suas características singulares. A mera consulta às fichas técnicas dos arquivos, acessíveis no portal CPDOC (www.fgv.br/cpdoc), por exemplo, mostraria que, ao contrário do que aparece referido em algumas passagens do livro, o critério funcional, 
centrado na trajetória de vida dos titulares dos arquivos e nas funções que exerceram, foi o eixo orientador da maioria dos arranjos utilizados nos arquivos pessoais sob a guarda do CPDOC. Não foi, é verdade, critério exclusivo nem dogmático, pois, dependendo das características específicas apresentadas por cada acervo, esse critério se articulou, por exemplo, com séries temáticas. Foi nesse espírito que, além de um 'método' sempre em aperfeiçoamento e que passou (e continua a passar) por transformações, também se desenvolveu na instituição um conjunto de reflexões sobre a natureza dos arquivos pessoais, desde a 'vontade de guardar' até as diferentes lógicas de disposição e de acesso a esses arquivos, passando pelos nexos estruturantes entre arquivos e 'escritas de si'.

Não é o caso aqui de aprofundar e exemplificar com mais densidade nem recuperar a história do desenvolvimento desse 'método CPDOC', mas sim, através da evocação de algumas de suas características, contrastá-lo com a tentativa, também recorrente no livro, de se submeter a organização dos arquivos pessoais de cientistas a um método supostamente alternativo, chamado de funcional. O problema principal, aqui, é adotar-se um quadro classificatório prévio e generalizável a qualquer arquivo pessoal, correndo-se o risco de se essencializar uma determinada 'natureza' dos arquivos pessoais, com base na criação de um modelo ideal a partir do qual eles devem ser organizados.

Um exemplo a esse respeito, presente no livro, é o caso do arquivo de Eugen Hussak, geólogo austríaco que atuou no Brasil entre finais do século XIX e início do XX, e que tanto por sua 'fluidez' profissional quanto pela prevalência de correspondência familiar em seu arquivo dificulta, no entender do responsável pela organização, "a consecução de uma proposta de organização calcada em um método de classificação funcional levando em consideração apenas o vínculo formal com uma instituição" (p.84). O risco é de caracterizarse (e organizar-se, como decorrência) um arquivo não por aquilo que ele tem, mas por aquilo que ele 'deveria' ter - preocupação, diga-se de passagem, claramente consciente para o autor/organizador desse arquivo. Num plano mais geral, há que se destacar o risco de uma leitura desistoricizante do que vem a ser trajetórias pessoais de cientistas, com todas as suas transformações: nas formas subjetivas de se dar testemunho de si através daquilo que se guarda; daquilo que é considerado ciência e, por extensão, quem são considerados verdadeiros cientistas; e de como as formas de pensar e organizar arquivos também são situadas historicamente.

Além dessas questões relativas à organização dos arquivos pessoais de cientistas, porém a elas ainda relacionadas, surgem outras mais gerais, igualmente estimuladas pela leitura do livro, ainda que não tenham sido explicitamente abordadas. O que afinal se entende por ciência, já que estamos falando de arquivos de cientistas? Quando se afirma que "o laboratório é o lugar da vida científica" e se erige o "caderno de protocolo de pesquisa" ou "caderno de laboratório" em documento fundamental do fazer científico (p.38), isso é válido para as ciências em geral, ou estamos falando de um tipo particular e historicamente condicionado de definição do que é ciência e cientista? Arquivos de matemáticos e de cientistas sociais, por exemplo, se encaixariam nesse padrão? O que seria, para eles, o 'laboratório'? Ou não seriam estas - as ciências matemáticas e sociais, ou ainda as 'humanidades' - plenamente científicas? O que, afinal, singularizaria a natureza dos arquivos pessoais 'de cientistas' em relação aos arquivos pessoais 'em geral'? 
Rótulos como pesquisa, ciência e cientista talvez sejam mais bem compreendidos como o resultado de processos interativos, sempre em transformação, entre indivíduos que buscam (através de mecanismos de conflito, cooperação, negociação, acusação etc.) definir o alcance, a pertinência e as características dessas categorias. A tentativa de definir o que é 'essencial' no trabalho científico (e, por extensão, nos arquivos de seus praticantes) pode levar, em nome de uma adesão a princípios considerados por sua vez 'científicos' da arquivística, à utilização de categorias classificatórias alheias aos contextos histórico-culturais de acumulação dos arquivos pessoais.

É comum dizer-se que a qualidade de um livro é medida não apenas pelo que nele se lê, mas também pelas reflexões que sua leitura estimula. Por todos os exemplos que traz, mas também pelas questões que abre, esse livro contribui de maneira significativa para que se desenvolva uma reflexão mais amadurecida sobre a organização, preservação e divulgação de arquivos pessoais. 